\title{
Extra-Intestinal Manifestations of Familial Adenomatous Polyposis
}

\author{
Emma J. Groen MD, ${ }^{1}$ Annemieke Roos MD ${ }^{1}$ Friso L. Muntinghe MD, ${ }^{2}$ Roelien H. Enting \\ $\mathrm{MD}, \mathrm{PhD},{ }^{3}$ Jakob de Vries MD, PhD,${ }^{4}$ Jan H. Kleibeuker MD, PhD, ${ }^{5}$ Max J. H. Witjes MD, \\ $\mathrm{PhD},{ }^{6}$ Thera P. Links MD, PhD, ${ }^{1}$ and André P. van Beek, MD, $\mathrm{PhD}^{1}$
}

\footnotetext{
${ }^{1}$ Department of Endocrinology, University Medical Center Groningen, University of Groningen, De Brug 4.069, P.O. Box 30.001, 9700 RB Groningen, The Netherlands

${ }^{2}$ Department of Internal Medicine, University Medical Center Groningen, University of Groningen, Groningen, The Netherlands ${ }^{3}$ Department of Neurology, University Medical Center Groningen, University of Groningen, Groningen, The Netherlands

${ }^{4}$ Department of Surgery, University Medical Center Groningen, University of Groningen, Groningen, The Netherlands ${ }^{5}$ Department of Gastroenterology, University Medical Center Groningen, University of Groningen, Groningen, The Netherlands ${ }^{6}$ Department of Oral and Maxillofacial Surgery, University Medical Center Groningen, University of Groningen, Groningen,
} The Netherlands

\begin{abstract}
Familial adenomatous polyposis (FAP) is an autosomal dominantly inherited disorder, which results from a germ line mutation in the APC (adenomatous polyposis coli) gene. FAP is characterized by the formation of hundreds to thousands of colorectal adenomatous polyps. Although the development of colorectal cancer stands out as the most prevalent complication, FAP is a multisystem disorder of growth. This means, it is comparable to other diseases such as the MEN syndromes, Von Hippel-Lindau disease and neurofibromatosis. However, the incidence of many of its clinical features is much lower. Therefore, a specialized multidisciplinary approach to optimize health care - common for other disorders - is not usually taken for FAP patients. Thus, clinicians that care for and counsel members of high-risk families should have familiarity with all the extra-intestinal manifestations of this syndrome. FAPrelated complications, for which medical attention is essential, are not rare and their estimated lifetime risk presumably exceeds $30 \%$. Affected individuals can develop thyroid and pancreatic cancer, hepatoblastomas, CNS tumors (especially medulloblastomas), and various benign tumors such as adrenal adenomas, osteomas, desmoid tumors and dental abnormalities. Due to improved longevity, as a result of better prevention of colorectal cancer, the risk of these clinical problems will further increase.We present a clinical overview of extra-intestinal manifestations, including management and treatment options for the FAP syndrome. Furthermore, we provide recommendations for surveillance of FAP complications based on available literature.
\end{abstract}

Key Words: Familial adenomatous polyposis-Extra-intestinal manifestations-Multisystem disorder.

In the early 1950 s, Gardner described that in some patients hereditary polyposis could occur simultaneously with multiple cutaneous and subcutaneous

\footnotetext{
Published online July 9, 2008.

Address correspondence and reprint requests to: André P. van Beek, MD, PhD; E-mail: a.p.van.beek@int.umcg.nl Published by Springer Science+Business Media, LLC $\odot$ The Author(s) 2008
}

lesions and osteomatosis. ${ }^{1}$ Initially, the triad of extraintestinal manifestations composed of soft tissue cysts, osteomas and dental abnormalities was referred to as Gardner syndrome. This terminology is now used only from a historical point of view. Indeed, retrospective research proved that extra-intestinal tumors could be found in almost all families with familial adenomatous polyposis (FAP), if the affected 


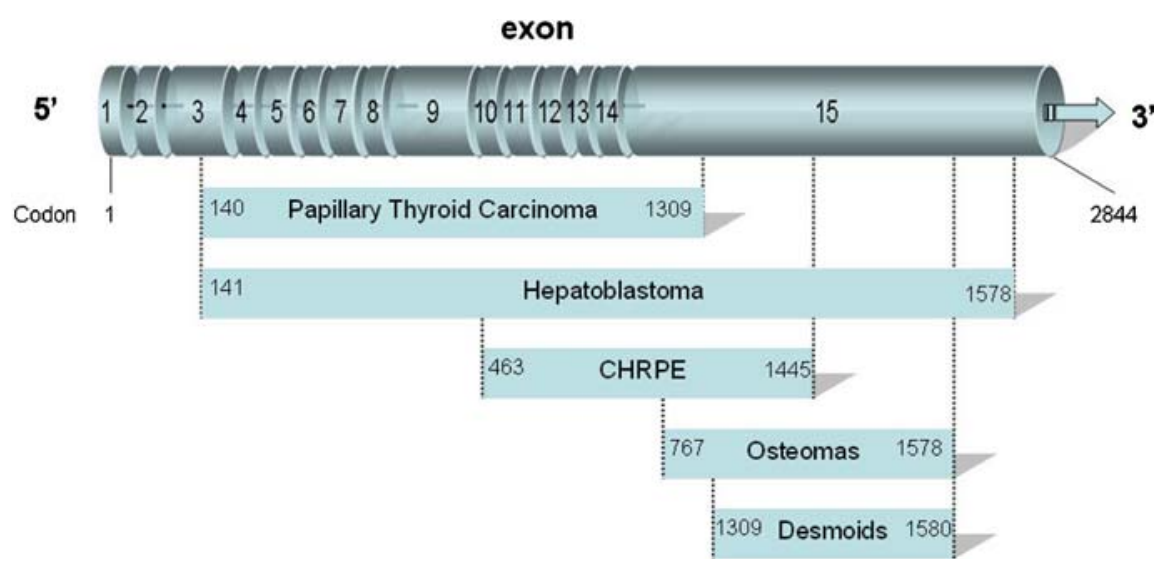

FIG. 1. Genotype-phenotype correlations of extra-intestinal familial adenomatous polyposis (FAP) manifestations according to the available literature. ${ }^{21,39,109,111}$ The APC gene consists of 15 exons. The highest cumulative frequencies of extra-colonic manifestations are found between codons 976-1,067 and 1,310-2,011. The margins of codon regions associated with extra-intestinal manifestations are not absolute and merely provide a guideline. No genotype-phenotype correlations have been established for pancreatic carcinoma, brain tumors or adrenal gland adenomas. CHRPE congenital hypertrophy of the retinal pigment epithelium.

patients were examined carefully. ${ }^{2}$ FAP is not uncommon with an incidence reported to vary from $1: 6,850$ to $1: 23,700$ live births ${ }^{3-5}$ and leads to development of colorectal carcinoma in almost $100 \%$ of cases by 40 years of age. The introduction and work of (national) polyposis registries and prophylactic colectomy has greatly improved life expectancy for patients with FAP. ${ }^{6,7}$

Surveillance recommendations for the prevention of other intestinal malignancies, such as duodenal ampullary carcinomas and gastric carcinomas, have been issued and are widely implemented. ${ }^{8-11}$ In contrast, less attention has been given to the diverse extra-intestinal features of FAP. Clinical awareness of health problems that are (seemingly) not related to intestinal manifestations is necessary because improved life expectancy in FAP patients has increased their prevalence.

In this paper, we review the extra-intestinal manifestations of FAP. To facilitate risk assessment of identified adenomatous polyposis coli (APC) gene mutations, a guideline of well-established genotypephenotype correlations is provided (Fig. 1). In addition, recommendations for surveillance are given for extra-intestinal malignancies (Table 1) and benign manifestations (Table 2). The commonly used GRADE criteria were used to describe both the strength of recommendations (1-4) and the quality of evidence (A-D).

\section{MOLECULAR GENETICS}

The APC gene located on $5 \mathrm{q} 21-22$ is mutated in FAP. Most mutations will result in stop codons and lead to truncation of the APC gene product. These mutations have a nearly complete penetrance of the colonic phenotype, but a variable penetrance of extra-colonic manifestations of the disease. Modifier genes, variable interference of different mutant APC proteins on the wild-type APC function and environmental factors may play a role in extra-intestinal tumor formation. $^{12}$

The APC protein is a large scaffolding protein with several functions. ${ }^{13}$ It is involved in the Wnt signaling cascade. As part of a multiprotein complex, the APC protein downregulates $\beta$-catenin activity. ${ }^{14}$ In the absence of a Wnt signal, APC forms a complex with the protein $\beta$-catenin, allowing it to be targeted for destruction. When APC function is lost, $\beta$-catenin accumulates in the cytoplasm and binds to several transcription factors of the TCF/LEF, thereby altering the expression of various genes affecting proliferation, differentiation, migration and apoptosis of cells. ${ }^{13}$ In addition, APC stabilizes microtubules, leading to chromosomal stability. ${ }^{15,16}$ Inactivation of APC can lead to defective chromosome segregation and aberrant mitosis. ${ }^{17}$

\section{FAP AND THYROID CARCINOMA}

\section{Epidemiology and Genetics}

Thyroid cancer in a patient with FAP was first described in 1949 by Crail. ${ }^{18}$ Almost 40 years later, Plail and coworkers reviewed 998 patients with FAP and found that thyroid carcinoma occurred more frequent in FAP patients than in the general popu- 
TABLE 1. Recommendations for surveillance of malignant extra-intestinal manifestations of familial adenomatous polyposis

\begin{tabular}{|c|c|c|c|c|}
\hline Manifestation & $\begin{array}{l}\text { Population } \\
\text { at risk }\end{array}$ & $\begin{array}{l}\text { Lifetime } \\
\text { prevalence }\end{array}$ & $\begin{array}{l}\text { Recommendation } \\
\text { for surveillance }\end{array}$ & Additional diagnostic considerations \\
\hline $\begin{array}{l}\text { Papillary thyroid } \\
\text { carcinoma }\end{array}$ & $\begin{array}{l}\text { Women, } 15-35 \text { years } \\
\text { Concomitant CHRPE } \\
\text { Family history of } \\
\text { thyroid carcinoma }\end{array}$ & $1-2 \%$ & $\begin{array}{l}\text { Look for palpable nodules } \\
\text { at least yearly and refer } \\
\text { to endocrinologist for } \\
\text { FNAB if present } \\
\text { Level 3, B: Sigurdson }\end{array}$ & 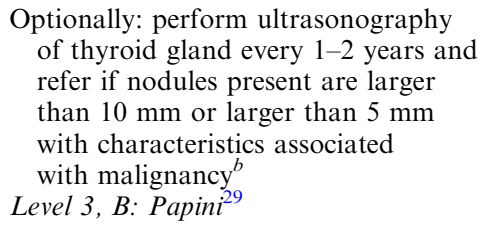 \\
\hline Hepatoblastoma & $\begin{array}{l}\text { Boys, } 0-4 \text { years, but } \\
\text { may present up to } \\
16 \text { years } \\
\text { Family history } \\
\text { of hepatoblastoma }\end{array}$ & $1-2 \%$ & $\begin{array}{l}\text { Serial measurement of aFP } \\
\text { Abdominal ultrasound } \\
\text { Suspicious hepatic lesions: } \\
\text { CT or MRI } \\
\text { Surveillance should } \\
\text { commence within the first } \\
\text { month after birth and } \\
\text { continued every } 3 \text { months } \\
\text { at least up to the age } \\
\text { of } 4 \text { years }{ }^{38} \\
\text { Level } 4, D \text { : Thomas }{ }^{36} \\
\text { Aretz, }{ }^{38} \text { Sanders }{ }^{43}\end{array}$ & \\
\hline Brain tumor & $\begin{array}{l}\text { Medulloblastoma: } \\
5-38 \text { years } \\
\text { Other brain tumors: } \\
22-80 \text { years } \\
\text { Family history } \\
\text { of brain tumor }\end{array}$ & $1-2 \%$ & $\begin{array}{l}\text { Surveillance not } \\
\quad \text { recommended } \\
\text { Level 4, D: this article }\end{array}$ & $\begin{array}{l}\text { Awareness of signs and symptoms } \\
\text { related to CNS tumors }\end{array}$ \\
\hline $\begin{array}{l}\text { Pancreatic } \\
\text { cancer }\end{array}$ & $> \pm 30$ years & $1 \%$ & $\begin{array}{l}\text { Surveillance not } \\
\text { recommended } \\
\text { Level 4, D: this article }\end{array}$ & $\begin{array}{l}\text { Awareness of signs and symptoms } \\
\text { related to pancreatic cancer } \\
\text { Pay attention to the pancreas } \\
\text { at CT or MRI }\end{array}$ \\
\hline
\end{tabular}

CHRPE congenital hypertrophy of the retinal pigment epithelium, FNAB fine needle aspiration biopsy.

${ }^{a}$ Supplementary to those defined by codon mutation (as depicted in Fig. 1).

${ }^{b}$ Hypoechogenic nodules, irregular margins, hypervascularity or microcalcifications.

lation. ${ }^{19}$ The largest FAP registries have reported a life time risk of $1-2 \%,{ }^{19,20}$ but some consider this an underestimation. $^{21}$ There is a striking female preponderance (female to male ratio $17: 1$ ). The average age at diagnosis is 27 years. It has never been found to present before 15 years of age. ${ }^{22}$ Young women (less than 35 years of age) are at particular risk of developing thyroid cancer, and their chances of being affected are approximately 160 times that of normal individuals. ${ }^{19}$ Familial clustering has been described several times. ${ }^{23}$ A strong association with Congenital Hyperplasia of the Retinal Pigment Epithelium (CHRPE, see below) exists - since most of the mutations cluster in the genomic area, characteristic of both extra-colonic manifestations. Genetic analysis most often shows a mutation in exon 15 , in the 5 , portion of the APC gene outside the Mutational Cluster Region (i.e., before codon 1,220).

\section{Clinical Findings}

Papillary thyroid carcinoma (PTC) almost invariably presents as a node in the thyroid gland. Other thyroid carcinomas have been described but are very rare. Fine needle aspiration biopsy (FNAB) of the node will establish the diagnosis, but sometimes a diagnostic hemithyroidectomy is necessary. The histological pattern typically shows a cribriform (morular) papillary thyroid carcinoma, but this is not entirely specific. Although multifocality in the thyroid gland and regional lymph node involvement often occur, FAP-associated PTC is a relatively indolent tumor. Treatment of PTC initially consists of total thyroidectomy and administration of radioiodine (131-I), followed by TSH suppression therapy. As a group, the prognosis is very favorable, with recurrence-free patient survival of more than 15 years. $^{21,23}$ After proper treatment, patients with no distant metastases are likely to have a normal residual lifespan. $^{24,25}$

\section{Considerations for Surveillance}

Thyroid surveillance in patients with FAP syndrome is recommended due to the known increased risk of thyroid cancer in this group and the ease and 
TABLE 2. Recommendations for surveillance of benign extra-intestinal manifestation of familial adenomatous polyposis

\begin{tabular}{|c|c|c|c|c|}
\hline Manifestation & Population at risk $^{a}$ & $\begin{array}{l}\text { Lifetime } \\
\text { prevalence }\end{array}$ & $\begin{array}{l}\text { Recommendation } \\
\text { for surveillance }\end{array}$ & $\begin{array}{l}\text { Additional diagnostic } \\
\text { considerations }\end{array}$ \\
\hline Adrenal tumors & $>14$ years & $7-13 \%$ & $\begin{array}{l}\text { Surveillance not recommended } \\
\text { Refer to endocrinologist if } \\
\text { adrenal adenoma is present } \\
\text { at CT or MRI } \\
\text { Level } 4, D \text { this article }\end{array}$ & $\begin{array}{l}\text { Adrenal adenomas can produce cortisol, } \\
\text { aldosterone, androgens or catecholamines } \\
\text { Pay attention to signs or symptoms related } \\
\text { to excess of these hormones (e.g., moon- } \\
\text { face, striae, hypertension, hirsutism) } \\
\text { Diagnostic work-up according } \\
\text { to NIH Guideline } 81\end{array}$ \\
\hline Desmoid tumors & $\begin{array}{l}\text { Peak incidence } \pm 30 \text { years } \\
\text { After surgery } \\
\quad \text { (median time } \pm 2 \text { years) } \\
\text { Family history } \\
\text { of desmoid tumors } \\
\text { Presence of osteomas }\end{array}$ & $20 \%$ & $\begin{array}{l}\text { Surveillance not recommended } \\
\text { Level } 4, D \text { : this article }\end{array}$ & $\begin{array}{l}\text { Evaluate palpable abdominal } \\
\text { masses or symptoms related to } \\
\text { abdominal organ obstruction } \\
\text { Optionally: consider CT } \\
\text { or MRI scan } \\
\text { Level 3, C: Healy }\end{array}$ \\
\hline Osteomas & $\begin{array}{l}\text { Presence of CHRPE } \\
\text { or desmoids } \\
\text { Positive family history } \\
\text { of osteomas }\end{array}$ & $20 \%$ & $\begin{array}{l}\text { Surveillance not recommended } \\
\text { Level } 4, D \text { this article }\end{array}$ & $\begin{array}{l}\text { Pay attention to mandibula problems. } \\
\text { Refer to dental surgeon if osteomas } \\
\text { cause problems. Various bone } \\
\text { localizations are possible }\end{array}$ \\
\hline $\begin{array}{l}\text { Dental } \\
\text { abnormalities }\end{array}$ & $\begin{array}{l}\text { Children/during dental } \\
\text { development }\end{array}$ & $17 \%$ & $\begin{array}{l}\text { Refer to dentist or dental surgeon } \\
\text { Serial OPG every } 1-2 \text { years } \\
\text { Level } 4, D: \text { Wijn, }{ }^{101} \text { this article }\end{array}$ & \\
\hline
\end{tabular}

CHRPE congenital hypertrophy of the retinal pigment epithelium, $O P G$ orthopantomography (panorex).

${ }^{a}$ Supplementary to those defined by codon mutation (as depicted in Fig. 1).

simplicity of the surveillance program. Recommendations are comparable to those for populations at high-risk of thyroid cancer, such as childhood cancer survivors who received radiotherapy to the head, neck or upper region. ${ }^{26}$ Although no specific protocols are available, physical examination of the neck and thyroid gland can be advocated. ${ }^{26}$ FNA - in case of suspected nodules - is recommended..$^{27,28}$ The use of (color Doppler) ultrasonography for thyroid gland examination is still controversial, but makes it possible to analyze non-palpable thyroid nodules and assess potentially malignant characteristics. ${ }^{29}$

\section{FAP AND HEPATOBLASTOMAS}

\section{Epidemiology and Genetics}

Hepatoblastoma is an embryonal neoplasm composed of malignant epithelial tissue with variable differentiation, most often with embryonal or fetal components. The tumor predominantly occurs in children between 6 months and 3 years of age, but the age at diagnosis can range from prenatal stages to 16 years. The clinical association between hepatoblastoma and FAP was first reported by Kingston et al. in $1983,{ }^{30}$ and more than 50 cases have now been reported. ${ }^{31}$ However, hepatoblastomas are also related to several other genetic abnormalities and malformation syndromes, the most important of which are Beckwith-Wiedemann syndrome, trisomy 18, fetal alcohol syndrome and extreme premature birth. ${ }^{32}$ The risk of hepatoblastoma is $750-7,500$ times higher in children from FAP families than in the general population. ${ }^{33,34}$ This higher incidence contributed significantly to the observed increased cancer mortality in the age group between 1 and 4 years in a Japanese polyposis registry; ${ }^{35}$ however, the absolute risk for hepatoblastoma in children with FAP is less than $2 \%{ }^{33}$ Familial clustering of hepatoblastomas has been described several times (reviewed by Thomas et al. ${ }^{36}$ ). The age at diagnosis and the increased incidence in boys is similar between FAP- and non-FAP-related hepatoblastomas. ${ }^{37}$ Mutation analysis revealed that almost $95 \%$ of the mutations were on the 5' to mid region of the APC gene between codons 141 and $1,751 .^{37,38}$ However, it is generally accepted that the site of the APC mutation cannot be used to predict the occurrence of hepatoblastoma. ${ }^{39}$ Because FAP and hepatoblastoma are rare, the precise epidemiological relationship between these diseases has been difficult to quantify.

\section{Clinical Findings}

Hepatoblastoma presents as an abdominal mass. While often asymptomatic in early stages, patients typically present with constipation, abdominal pain, 
vomiting, weight loss, anemia and thrombocytosis in advanced tumors. The diagnosis is confirmed by an elevated $\alpha$-fetoprotein $(\alpha \mathrm{FP})$ in approximately $90 \%$ of cases, by liver imaging and, ultimately, by biopsy. ${ }^{40}$ Survival is highly related to the success of complete tumor resection. ${ }^{38}$ Preoperative chemotherapy (usually consisting of cisplatin and doxorubicin) is very helpful and many previously irresectable tumors can become completely amenable to surgery. Although the combination of chemotherapy and surgery is very successful, an estimated $25 \%$ of all patients do not survive this disease. ${ }^{38,41}$

\section{Considerations for Surveillance}

There are no validated and generally accepted guidelines of surveillance for hepatoblastoma in FAP families. According to their recently published surveillance protocol, Aretz et al. recommend analysis of (changes in) serial $\alpha \mathrm{FP}$ measurements and abdominal ultrasound. Suspicious hepatic lesions on sonography should be further investigated with CT or MRI. Surveillance should commence within the first month after birth and continued every 3 months at least up to the age of 4 years. ${ }^{38}$ Due to limitations in the interpretation of $\alpha \mathrm{FP}$ as a marker for hepatoblastoma at a very young age or due to the lack of $\alpha \mathrm{FP}$ production in undifferentiated tumors, false-positive or false-negative results can be obtained. When the classical criteria of Wilson and Jungner are applied for surveillance, it remains questionable whether the diagnostic tests are suitable. ${ }^{42}$ However, the disease is more easily curable if detected at an early stage, and several authors thus favor surveillance of young children in FAP families. ${ }^{36,38,43}$

\section{FAP AND BRAIN TUMORS}

\section{Epidemiology and Genetics}

In 1959, Turcot and colleagues described two teenaged siblings with numerous adenomatous polyps of the colorectum in whom malignant tumors of the central nervous system (CNS) developed. ${ }^{44}$ The association of primary brain tumors and colorectal polyposis has since been described in the literature under the eponym "Turcot's syndrome". The association between brain tumors and colorectal polyposis has been renamed the "brain tumor-polyposis" (BTP) syndrome. ${ }^{45}$ Both clinically ${ }^{45}$ and molecularly, ${ }^{46}$ this appeared to be a heterogeneous disorder with at least two clinical entities. The BTP syndrome type 1 results from mutations in DNA mismatch repair genes characteristic of Lynch syndrome or hereditary non-polyposis colorectal cancer (HNPCC). The brain tumors are usually high-grade astrocytomas or glioblastomas. ${ }^{45}$ It is also referred to as "true Turcot's syndrome". It should be noted that the original description of Turcot is confusing, because what he described was most likely a HNPCC case with (few) colon polyps. The BTP syndrome type 2 typically consists of a medulloblastoma associated with colorectal polyposis in a patient who belongs to a FAP family. ${ }^{45}$ In the context of this review, we have focused on FAP-associated brain tumors. The terminology of BTP or Turcot's syndrome is preferentially used only from a historical point of view.

Medulloblastomas account for $80 \%$ of the brain tumors found in FAP. However, high-grade astrocytomas and ependymomas have also been described. ${ }^{46}$ Medulloblastoma is a highly malignant embryonal CNS tumor primarily affecting children in the first decade of life, and $70 \%$ occurs before the age of 16 years. The relative lifetime risk of any brain tumor among members from a FAP family is increased by a factor 7 , and that of medulloblastoma by a factor 90 . However, the absolute lifetime risk of any brain tumor is approximately $1-2 \%{ }^{46}$

\section{Clinical Findings}

Medulloblastoma generally occurs in the midline cerebellum and, therefore, presents with signs or symptoms of obstructive hydrocephalus and cerebellar dysfunction, usually over a period of weeks to months. Typical symptoms are emesis, horizontal diplopia, clumsiness or frank ataxia, and headaches. Currently, patients with medulloblastoma are best treated with surgical removal of the tumor, radiation therapy and/or chemotherapy depending on age, extent of resection and presence of metastases. ${ }^{47}$ The overall 5-year survival has risen to $50-70 \%$ in the past decades. The median overall survival appeared to be much longer among patients who present with colon polyps first. ${ }^{48}$ This observation has to be confirmed in other series of patients.

\section{Considerations for Surveillance}

There are a number of familial syndromes that predispose individuals to CNS tumors; examples are von Hippel-Lindau (VHL) disease and neurofibromatosis type 1 (NF-1). The lifetime risk of CNS hemangioblastomas in VHL is $60-80 \%$. Improved surveillance of patients at risk for VHL disease, 
including yearly MRI of the craniospinal axis from the age of 11 years, has substantially improved diagnosis and treatment. ${ }^{49}$ Optic nerve gliomas are seen in $15 \%$ of patients with NF-1. Patients with NF1 are usually seen by a multidisciplinary clinical team. Cranial MRIs for the detection of these gliomas are usually reserved for children with abnormalities during their annual vision evaluation. ${ }^{50}$ In contrast to these familial syndromes, brain tumors in FAP families are associated with a much lower lifetime risk. Furthermore, annual surveillance of asymptomatic patients may not be often enough, since medulloblastoma is a highly malignant tumor that is usually only symptomatic 6 months or less before diagnosis. Therefore, surveillance by means of regular CT or MRI cannot be advocated. However, members from a FAP family who do not yet have polyposis, but do have signs or symptoms suggestive of a brain tumor, should be evaluated with neuro-imaging because brain tumors present before the diagnosis of polyposis in over half of the FAP patients. ${ }^{46}$ Careful evaluation is also important among FAP families in which one member already has a brain tumor since familial clustering occurs. Of such families with FAPassociated brain tumors, $40 \%$ had two affected members. ${ }^{46}$ Doctors who care for members of FAP families should be aware of the association with medulloblastoma and, thus, increase their sensitivity to signs or symptoms of CNS tumors. Additionally, education of members of FAP families about extracolonic manifestations could be useful.

\section{FAP AND PANCREATIC TUMORS}

\section{Epidemiology and Genetics}

Pancreatic tumors in FAP patients are rare. In a cohort study of 1,391 patients with FAP reported in the Johns Hopkins Registry, 4 patients were found to have developed a pancreatic adenocarcinoma. ${ }^{51}$ Their age ranged from 32 to 78 years. From this, a significantly higher relative risk [RR: 4.5 (95\% confidence limits $1.2-11.4$ )] of pancreatic carcinoma was calculated in polyposis patients and their relatives than in the general population. Few other types of pancreatic malignancies have been described. Two cases of intraductal papillary-mucinous neoplasm, ${ }^{52,53}$ one cystic and papillary carcinoma, ${ }^{54}$ one acinar cell carcinoma $^{55}$ and two islet cell tumors ${ }^{56,57}$ have been reported in association with FAP. In addition, some pancreatic premalignant lesions ${ }^{58-60}$ and a pancreatic cyst due to desmoid fibromatosis in a 17 -year-old male ${ }^{61}$ have been described. No evidence of familial clustering is evident from the literature.

\section{Clinical Findings}

Pancreatic carcinomas are often clinically silent for a long time. In more advanced stages, patients may experience pain, weight loss, jaundice or diarrhea (steatorrhea). Diabetes, pancreatitis and thrombophlebitis also occur. The prognosis of adenocarcinomas of the pancreas is generally poor. Treatment options consist of surgery and chemotherapy. ${ }^{62}$

\section{Considerations for Surveillance}

In view of the low prevalence of pancreatic cancer and the scarcity of published data, surveillance is not routinely recommended. Future protocols may include MR imaging and endoscopic ultrasonography (EUS). ${ }^{63}$ The clinician should be aware that pancreatic neoplasia can develop. When abdominal imaging is performed, for example in the evaluation of desmoid tumors or adrenal gland adenomas, attention should be given to potential abnormalities in the pancreas.

\section{FAP AND ADRENAL TUMORS}

\section{Epidemiology and Genetics}

Adrenal adenomas are frequently occurring extraintestinal manifestations of FAP. The first case of a FAP patient with an adrenal adenoma was published almost a century ago ${ }^{64}$ Since then, approximately 50 cases have been reported in the literature, many of them being asymptomatic and discovered at autopsy. ${ }^{65-76}$ Age ranges from 14 to 70 years, with a median of approximately $40-50$ years. As a result of technological advances in imaging techniques such as $\mathrm{CT}$ and MRI during the last decades, new information has become available regarding the prevalence of adrenal masses in both the general population and patients with FAP. In a retrospective study, Marchesa et al. found a 7\% prevalence of so-called "incidentalomas" in FAP patients, ${ }^{69}$ compared with approximately $3 \%$ in the general population. ${ }^{77}$ Smith et al. even showed a prevalence of adrenal masses of $13 \%$ in a prospective study. ${ }^{74}$ Familial clustering has also been described. ${ }^{71}$ Although the prevalence of adrenal masses in FAP patients are two to four times as high as in the general population, the clinical presentation, and biological behavior do not seem to be different. ${ }^{69,74}$ 
Most adrenal adenomas do not produce hormones, although production of cortisol, ${ }^{66,69,76}$ aldosterone ${ }^{65}$ and their combination have been reported. ${ }^{73}$ Smith et al. described a patient with a pheochromocytoma. ${ }^{74}$ Data on genetic analysis are limited, and only three mutations have been described (codons 1,061, 1,542 and 1,981). The latter was associated with multiple and bilateral adenomas. ${ }^{68}$ Adrenal carcinomas in association with FAP are very rare and only six have been described. ${ }^{69,70,72,78-80}$

\section{Clinical Findings}

Adrenal adenomas usually present as clinically unapparent adrenal masses, detected incidentally with imaging studies conducted for other reasons. The two major clinical concerns are that adrenal masses may overproduce hormones or that they represent adrenal cortical carcinomas. By definition, no clinical symptoms or signs of adrenal disease should be present at the time of diagnosis in patients with incidentally detected adrenal masses. However, a more detailed questioning and a careful physical examination might reveal subtle evidence for hormone excess. Hormonal assessment is usually done by an endocrinologist, in some countries also by an endocrine surgeon. In addition, repeat imaging after 6-12 months is necessary to assess malignant potential. Clinically silent lesions that are less than $4 \mathrm{~cm}$ are generally not resected. Surgery is indicated in adrenal masses larger than $6 \mathrm{~cm}$ because they frequently harbor malignancies and, in the case of hormone-producing adenomas, because of the metabolic consequences. For lesions between 4 and $6 \mathrm{~cm}$, with benign characteristics on imaging, that do not appear to overproduce hormones, both close followup and adrenalectomy are considered a reasonable approach. ${ }^{81}$

\section{Considerations for Surveillance}

Based on the low incidence of hormone-producing adrenal adenomas and the rarity of adrenal cancer in FAP patients, surveillance does not seem to be justified. However, clinical awareness is very important. Subtle clues such as weight gain, hypertension or hypokalemia and diabetes mellitus may prompt further hormonal analysis. Once a tumor in the adrenals is identified, hormonal and radiological evaluations according to the NIH conference guidelines need to be performed. ${ }^{81}$ Patients should be referred to an endocrinologist. This is especially important since recent reports suggest that up to $20 \%$ of patients with adrenal incidentaloma (which means 1-3\% of all FAP patients) have some form of subtle and subclinical hormonal dysfunction resulting in an increased risk of metabolic disorders and cardiovascular disease.

\section{FAP AND DESMOID TUMORS}

\section{Epidemiology and Genetics}

Desmoid tumors are a very important cause of mortality in patients with FAP. ${ }^{6}$ There is an approximate 1000 -fold increase of developing desmoid tumors in FAP patients when compared to the general population. ${ }^{82}$ Desmoids can be found at any age and have been documented from infancy to 81 years of age. ${ }^{83}$ The most common age of presentation is between 20 and 40 years, with a median age of 30 years, as reviewed by Knudsen et al ${ }^{84}$ The risk of such tumor formation is increased after prior surgery. Jarvinen found that the median interval between the operation and the diagnosis of desmoid was a little over 2 years. ${ }^{85}$ The lifetime risk associated with these tumors in a Finnish and Italian registry was estimated to be approximately $21 \% .^{86,87}$ The most important risk factors are a positive family history, presence of osteomas or epidermoid cysts and an APC gene mutation between codons 1,444 and $1,578 .^{86}$

\section{Clinical Findings}

Most desmoid tumors in FAP patients arise in the abdomen, most frequently intra-abdominally (in the mesentery of the small bowel) but also in the abdominal wall (some in surgical scars). Fewer than $10 \%$ are located outside the abdomen. ${ }^{83,88,89}$ Depending on localization, desmoid tumors can be either asymptomatic or cause pain and various gastrointestinal complaints. Mesenteric desmoids may cause small bowel obstruction, ureter compression, small intestinal ischemia, abscess formation, intestinal perforation or fistulas.

Desmoid tumors are poorly understood. They are infiltrative and non-metastasizing, with a histologically benign appearance apart from the surrounding tissue infiltration. Approximately $5-10 \%$ appear to resolve spontaneously. ${ }^{88,90}$ In addition, $30 \%$ undergo cycles of progression and resolution, and 50\% remain stable after diagnosis. However, $10 \%$ progress rapidly, growing to massive sizes and infiltrating adjacent structures. ${ }^{90}$ Treatment is indicated when they cause symptoms, pose a great risk to adjacent struc- 
tures or create cosmetic concerns. There are no controlled trials on the treatment of desmoid tumors. Furthermore, many studies of desmoids are confounded by inclusion of both FAP-associated and sporadic disease, which may represent two biologically distinct entities. ${ }^{91}$ Thus, treatment modalities are not well established. For intra-abdominally located tumors, treatment with sulindac (non-steroidal anti-inflammatory drug) and/or a selective estrogen receptor modulator (tamoxifen/torimifene) is advised as first line therapy. ${ }^{83,84,89}$ Cytotoxic chemotherapy has been used for desmoids that are not responsive to less aggressive therapies. ${ }^{61,83,84}$ Surgery is generally not recommended as first-line therapy for intra-abdominal desmoids because recurrence rate and morbidity are reported to be extremely high, including bleeding, short bowel and postoperative death (8 of 22 patients in the series from St. Marks), ${ }^{88}$ although a later report from the same group claimed that it was less hazardous than previously reported. ${ }^{92}$ In addition, it is commonly believed that resection triggers growth and therefore recurrences. However, when medical treatment of large mesenteric desmoids fails, surgery remains a valuable option. ${ }^{93}$

Surgery is indicated as first line therapy for tumors located in the abdominal wall and extra-abdominally. ${ }^{88}$ For patients with positive resection margins, adjuvant radiotherapy can be given..$^{94}$ Nevertheless, it can be argued that abdominal wall desmoids need not be resected, but can be observed as the natural history is variable and recurrence after surgery is frequent.

\section{Considerations for Surveillance}

There is no consensus about surveillance of patients with FAP with regard to the presence of desmoid tumors, principally because there are no real preventive strategies. Thus, some advocate no surveillance at all. However, because the mortality due to polyposis is decreasing and morbidity and mortality from desmoid tumors is increasing, it seems reasonable to look for intra-abdominally located desmoid tumors using CT or MRI scan, ${ }^{95}$ especially in patients with a gene mutation between codons 1,444 and 1,578 or in those with a family history of desmoids. Because desmoids often arise as a consequence of tissue trauma, a delay of surgery and the type of surgery should be considered in patients at high risk of developing desmoids, at least in those with a smaller number of polyps or when the onset of colon malignancies is expected to occur later in life. Mutation analysis may be of help in such cases as an aid in decision making. ${ }^{96-99}$ Ileal pouch-anal anastomosis is advocated as the appropriate type of surgery in FAP patients with a positive family history of desmoids. ${ }^{100}$

\section{FAP, OSTEOMAS AND DENTAL ABNORMALITIES}

\section{Epidemiology and Genetics}

The prevalence of osteomas is about $20 \%$ in FAP patients compared with $1-2 \%$ in the general population. Mutations are found in codons 767 to 1,578 . Dental abnormalities occur frequently with an estimated prevalence of $17 \% .{ }^{101}$ As with other manifestations, osteomas and dental abnormalities may also precede the actual development of colon polyps in FAP patients. ${ }^{102}$

\section{Clinical Findings}

Osteomas are benign bone growths most commonly found in the skull and mandible. However, they may occur in any bone of the body. ${ }^{103}$ Their size ranges from less than a millimeter to several centimeters. They can give rise to cosmetic concerns.

The dentition during childhood can be disturbed by the presence of supernumerary teeth, dentigerous cysts and a phenomenon referred to as secondary retention of teeth. Supernumerary teeth and dentigerous cysts can obstruct normal teeth from erupting. This is often an indication for surgical removal. Supernumerary teeth are usually present before the age of 10 years. The development of cysts can occur at any age. Dentigerous cysts are those that develop from the epithelium of the enamel organ; therefore, the risk of developing such a cyst is greatest when teeth are still developing in the jaw. They can sometimes grow and occupy more than a quarter of the mandible. Such cysts lead to local destruction of the jaw and removal can have profound consequences for the patient. The phenomenon of secondary retention of teeth has also been described in FAP patients. In such cases, erupted teeth are retained at a certain position in the jaw, which is usually caused by ankylosis. This results in a submerged position of the involved tooth. It is not necessary to treat such teeth when they do not obstruct the eruption of other teeth. When these teeth give problems, removal is usually the only option.

\section{Considerations for Surveillance}

A normal dentition is fully developed at 18 years of age. Disclosure at an early stage is therefore important 
in reducing the morbidity associated with surgical removal. The literature on dental anomalies in FAP patients is mainly restricted to a description of the pathology, ${ }^{104}$ and no surveillance recommendations have been published. In comparable syndromes with a high risk of developing cysts in the jaws, such as the nevoid basal cell carcinoma syndrome, it is recommended that a routine panorex is made every 12 years for early disclosure of cysts. ${ }^{105}$ The incidence of the development of dental anomalies in FAP is clearly increased relative to that in normal individuals, and treatment at a later age has been described as complicated. ${ }^{106}$ It is therefore recommended that in the routine follow-up, a panorex is included at least every 2 years in a developing child until the teeth have erupted $(\sim 18$ years $) .{ }^{101}$ In this way, problems caused by undetected dental abnormalities later in life can be prevented.

\section{FAP AND OTHER BENIGN MANIFESTATIONS}

Epidermoid cysts, fibromas and lipomas are all considered (sub)cutaneous lesions and may cause cosmetic problems. Cysts occasionally become infected, necessitating operative removal. Nasopharyngeal angiofibromas have been described in some patients with FAP syndrome. They occur 25 times more frequently in patients with FAP than in an agematched population. ${ }^{107}$

Congenital hypertrophy of the retinal pigment epithelium (CHRPE) is the most common extra-colonic manifestation of FAP and an early marker for it. Approximately $60 \%$ of patients with FAP have CHRPE. Multiple or bilateral patches of these lesions are highly specific $(95 \%)$ for FAP syndrome. ${ }^{108}$ It appears as well-demarcated grey-brown to black round or oval lesions in the retinae of affected individuals and is not known to cause any clinical problems. Mutations in the region between codons 543 and 1,309 in the APC gene are associated with a high risk of CHRPE. ${ }^{109}$ Ophthalmoscopic surveillance for CHRPE is a direct, non-invasive and inexpensive test. If the index case has CHRPE, then surveillance for CHRPE has been successfully used as an early clinical marker to detect affected family members. ${ }^{110}$

\section{CONCLUSION}

FAP is due to a germline mutation in the APC gene. The development of colorectal cancer stands out as the most characteristic manifestation of this disease. Prophylactic colectomy has improved the life expectancy of patients, as a result of which the prevalence of other manifestations has increased. In appreciation of the development of various forms of benign and malignant tumors, it seems more appropriate to speak of FAP syndrome. The diverse multisystem effects of FAP syndrome manifest during different phases of life and in association with different mutations. Some tumors can present during early childhood before the classical colonic polyps cause problems, and this may be the first clue that FAP is present. Many FAP cases are due to spontaneous mutations, with no antecedent family history, and many parents are poorly informed about their own FAP and cannot be counted on to connect their child's disease (for instance a hepatoblastoma or a brain tumor) with their own. Therefore, to optimize health care for FAP families, the surgeon and the gastroenterologist who are often the primary FAP experts also have a key role as education providers.

\section{SEARCH STRATEGY}

We searched the PubMed database using the keywords Familial Adenomatous Polyposis or Gardner syndrome, combined with the terms molecular genetics, thyroid carcinoma, hepatoblastoma, brain tumor, pancreatic tumor, adrenal tumor, desmoid tumor, osteoma, dental abnormalities or benign manifestations. We focused mainly on manuscripts published during the past 10 years, but have also referenced key papers from before then. In addition, relevant articles that were identified by papers found in this search strategy have also been referenced.

\section{OPEN ACCESS}

This article is distributed under the terms of the Creative Commons Attribution Noncommercial License which permits any noncommercial use, distribution, and reproduction in any medium, provided the original author(s) and source are credited.

\section{REFERENCES}

1. Gardner EJ, Richards RC. Multiple cutaneous and subcutaneous lesions occurring simultaneously with hereditary polyposis and osteomatosis. Am J Hum Genet 1953; 5:139-47.

2. Galiatsatos P, Foulkes WD. Familial adenomatous polyposis. Am J Gastroenterol 2006; 101:385-98. 
3. Bisgaard ML, Fenger K, Bulow S, et al. Familial adenomatous polyposis (FAP): frequency, penetrance, and mutation rate. Hum Mutat 1994; 3:121-5.

4. Bjork J, Akerbrant H, Iselius L, et al. Epidemiology of familial adenomatous polyposis in Sweden: changes over time and differences in phenotype between males and females. Scand $J$ Gastroenterol 1999; 34:1230-5.

5. Bulow S, Faurschou NT, Bulow C, et al. The incidence rate of familial adenomatous polyposis. Results from the Danish Polyposis Register. Int J Colorectal Dis 1996; 11:88-91.

6. Nugent KP, Spigelman AD, Phillips RK. Life expectancy after colectomy and ileorectal anastomosis for familial adenomatous polyposis. Dis Colon Rectum 1993; 36:1059-62.

7. Bulow S. Results of national registration of familial adenomatous polyposis. Gut 2003; 52:742-6.

8. Bjork $\mathbf{J}$, Akerbrant $\mathbf{H}$, Iselius $\mathbf{L}$, et al. Periampullary adenomas and adenocarcinomas in familial adenomatous polyposis: cumulative risks and APC gene mutations. Gastroenterology 2001; 121:1127-35.

9. Gallagher MC, Phillips RK, Bulow S. Surveillance and management of upper gastrointestinal disease in Familial Adenomatous Polyposis. Fam Cancer 2006; 5:263-73.

10. Hirota WK, Zuckerman MJ, Adler DG, et al. ASGE guideline: the role of endoscopy in the surveillance of premalignant conditions of the upper GI tract. Gastrointest Endosc 2006; 63:570-80.

11. Matsumoto T, Lida M, Kobori Y, et al. Genetic predisposition to clinical manifestations in familial adenomatous polyposis with special reference to duodenal lesions. Am J Gastroenterol 2002; 97:180-5.

12. Fearnhead NS, Britton MP, Bodmer WF. The ABC of APC. Hum Mol Genet 2001; 10:721-33.

13. Goss KH, Groden J. Biology of the adenomatous polyposis coli tumor suppressor. J Clin Oncol 2000; 18:1967-79.

14. Peifer $M$, Polakis $P$. Wnt signaling in oncogenesis and embryogenesis - a look outside the nucleus. Science 2000; 287:1606-9.

15. Fodde R, Kuipers J, Rosenberg C, et al. Mutations in the APC tumour suppressor gene cause chromosomal instability. Nat Cell Biol 2001; 3:433-8.

16. Fodde R, Smits R, Clevers H. APC, signal transduction and genetic instability in colorectal cancer. Nat Rev Cancer 2001; 1:55-67.

17. Kaplan KB, Burds AA, Swedlow JR, et al. A role for the Adenomatous Polyposis Coli protein in chromosome segregation. Nat Cell Biol 2001; 3:429-32.

18. Crail HW. Multiple primary malignancies arising in the rectum, brain and thyroid. Report of a case. US Navy Med Bull 1949; 49:123-8.

19. Plail RO, Bussey HJ, Glazer G, et al. Adenomatous polyposis: an association with carcinoma of the thyroid. Br J Surg 1987; 74:377-80.

20. Iwama T, Mishima Y, Utsunomiya J. The impact of familial adenomatous polyposis on the tumorigenesis and mortality at the several organs. Its rational treatment. Ann Surg 1993; 217:101-8.

21. Cetta F, Olschwang S, Petracci M, et al. Genetic alterations in thyroid carcinoma associated with familial adenomatous polyposis: clinical implications and suggestions for early detection. World J Surg 1998; 22:1231-6.

22. Cetta F, Montalto G, Gori M, et al. Germline mutations of the APC gene in patients with familial adenomatous polyposisassociated thyroid carcinoma: results from a European cooperative study. J Clin Endocrinol Metab 2000; 85:286-92.

23. Cetta F, Pelizzo MR, Curia MC, et al. Genetics and clinicopathological findings in thyroid carcinomas associated with familial adenomatous polyposis. Am J Pathol 1999; 155:7-9.

24. Bulow C, Bulow S. Is screening for thyroid carcinoma indicated in familial adenomatous polyposis? The Leeds Castle Polyposis Group. Int J Colorectal Dis 1997; 12:240-2.
25. Links TP, van Tol KM, Jager PL, et al. Life expectancy in differentiated thyroid cancer: a novel approach to survival analysis. Endocr Relat Cancer 2005; 12:273-80.

26. Sigurdson AJ, Ronckers CM, Mertens AC, et al. Primary thyroid cancer after a first tumour in childhood (the Childhood Cancer Survivor Study): a nested case-control study. Lancet 2005; 365:2014-23.

27. Cooper DS, Doherty GM, Haugen BR, et al. Management guidelines for patients with thyroid nodules and differentiated thyroid cancer. Thyroid 2006; 16:109-42.

28. Frates MC, Benson CB, Charboneau JW, et al. Management of thyroid nodules detected at US: Society of Radiologists in Ultrasound consensus conference statement. Radiology 2005; 237:794-800.

29. Papini E, Guglielmi R, Bianchini A, et al. Risk of malignancy in nonpalpable thyroid nodules: predictive value of ultrasound and color-Doppler features. J Clin Endocrinol Metab 2002; 87:1941-6.

30. Kingston JE, Herbert A, Draper GJ, et al. Association between hepatoblastoma and polyposis coli. Arch Dis Child 1983; 58:959-62.

31. Su LK, Abdalla EK, Law CH, et al. Biallelic inactivation of the APC gene is associated with hepatocellular carcinoma in familial adenomatous polyposis coli. Cancer 2001; 92:332-9.

32. von Schweinitz D. Neonatal liver tumours. Semin Neonatol 2003; 8:403-10.

33. Hughes LJ, Michels VV. Risk of hepatoblastoma in familial adenomatous polyposis. Am J Med Genet 1992; 43:1023-5.

34. Giardiello FM, Offerhaus GJ, Krush AJ, et al. Risk of hepatoblastoma in familial adenomatous polyposis. J Pediatr 1991; 119:766-8.

35. Iwama T, Mishima Y. Mortality in young first-degree relatives of patients with familial adenomatous polyposis. Cancer 1994; 73:2065-8.

36. Thomas D, Pritchard J, Davidson R, et al. Familial hepatoblastoma and APC gene mutations: renewed call for molecular research. Eur J Cancer 2003; 39:2200-4.

37. Hirschman BA, Pollock BH, Tomlinson GE. The spectrum of APC mutations in children with hepatoblastoma from familial adenomatous polyposis kindreds. J Pediatr 2005; 147:263-6.

38. Aretz S, Koch A, Uhlhaas S, et al. Should children at risk for familial adenomatous polyposis be screened for hepatoblastoma and children with apparently sporadic hepatoblastoma be screened for APC germline mutations? Pediatr Blood Cancer 2006; 47:811-8.

39. Giardiello FM, Petersen GM, Brensinger JD, et al. Hepatoblastoma and APC gene mutation in familial adenomatous polyposis. Gut 1996; 39:867-9.

40. Phillips M, Dicks-Mireaux C, Kingston J, et al. Hepatoblastoma and polyposis coli (familial adenomatous polyposis). Med Pediatr Oncol 1989; 17:441-7.

41. Schnater JM, Kohler SE, Lamers WH, et al. Where do we stand with hepatoblastoma? A review. Cancer 2003; 98:668-78.

42. Wilson JMG, Jungner G. Principles and practice of screening for diseases. Geneva, WHO chronicle 1968; 22:1-163.

43. Sanders RP, Furman WL. Familial adenomatous polyposis in two brothers with hepatoblastoma: implications for diagnosis and screening. Pediatr Blood Cancer 2006; 47:851-4.

44. Turcot J, Despres JP, St Pierre F. Malignant tumors of the central nervous system associated with familial polyposis of the colon: report of two cases. Dis Colon Rectum 1959; 2:4658.

45. Paraf F, Jothy S, Van Meir EG. Brain tumor-polyposis syndrome: two genetic diseases? J Clin Oncol 1997; 15:2744-58.

46. Hamilton SR, Liu B, Parsons RE, et al. The molecular basis of Turcot's syndrome. $N$ Engl J Med 1995; 332:839-47.

47. Rood BR, Macdonald TJ, Packer RJ. Current treatment of medulloblastoma: recent advances and future challenges. Semin Oncol 2004; 31:666-75. 
48. Van Meir EG. "Turcot's syndrome": phenotype of brain tumors, survival and mode of inheritance. Int J Cancer 1998; $75: 162-4$

49. Lonser RR, Glenn GM, Walther M, et al. von Hippel-Lindau disease. Lancet 2003; 361:2059-67.

50. Reynolds RM, Browning GG, Nawroz I, et al. Von Recklinghausen's neurofibromatosis: neurofibromatosis type 1 . Lancet 2003; 361:1552-4.

51. Giardiello FM, Offerhaus GJ, Lee DH, et al. Increased risk of thyroid and pancreatic carcinoma in familial adenomatous polyposis. Gut 1993; 34:1394-6.

52. Maire F, Hammel P, Terris B, et al. Intraductal papillary and mucinous pancreatic tumour: a new extracolonic tumour in familial adenomatous polyposis. Gut 2002; 51:446-9.

53. Sudo T, Murakami Y, Uemura K, et al. Development of an intraductal papillary-mucinous neoplasm of the pancreas in a patient with familial adenomatous polyposis. Pancreas 2005 31:428-9.

54. Le Borgne J, Bouvier S, Fiche M, et al. Cystic and papillary tumor of the pancreas: diagnostic and developmental uncertainties. Apropos of a case. Chirurgie 1997; 122:31-4.

55. Seket B, Saurin JC, Scoazec JY, et al. Pancreatic acinar cell carcinoma in a patient with familial adenomatous polyposis Gastroenterol Clin Biol 2003; 27:818-20.

56. Schneider NR, Cubilla AL, Chaganti RS. Association of endocrine neoplasia with multiple polyposis of the colon. Cancer 1983; 51:1171-5.

57. Stewart CJ, Imrie CW, Foulis AK. Pancreatic islet cell tumour in a patient with familial adenomatous polyposis. J Clin Pathol 1994; 47:860-1.

58. Chetty R, Salahshor S, Bapat B, et al. Intraductal papillary mucinous neoplasm of the pancreas in a patient with attenuated familial adenomatous polyposis. J Clin Pathol 2005; 58:97-101.

59. Gupta C, Mazzara PF. High-grade pancreatic intraepithelial neoplasia in a patient with familial adenomatous polyposis. Arch Pathol Lab Med 2005; 129:1398-400.

60. Komorowski RA, Tresp MG, Wilson SD. Pancreaticobiliary involvement in familial polyposis coli/Gardner's syndrome. $D i$ s Colon Rectum 1986; 29:55-8.

61. Pho LN, Coffin CM, Burt RW. Abdominal desmoid in familial adenomatous polyposis presenting as a pancreatic cystic lesion. Fam Cancer 2005; 4:135-8.

62. Lockhart AC, Rothenberg ML, Berlin JD. Treatment for pancreatic cancer: current therapy and continued progress. Gastroenterology 2005; 128:1642-54.

63. Canto MI, Goggins M, Hruban RH, et al. Screening for early pancreatic neoplasia in high-risk individuals: a prospective controlled study. Clin Gastroenterol Hepatol 2006; 4:766-81.

64. Devic A, Bussy MM. Un cas de polypose adénomateuse: Generalisée à tout l'intestin. Arch Mal Appar Dig 1912; 6:27889.

65. Alexander GL, Thompson GB, Schwartz DA. Primary aldosteronism in a patient with familial adenomatous polyposis. Mayo Clin Proc 2000; 75:636-7.

66. Beuschlein F, Reincke M, Koniger M, et al. Cortisol producing adrenal adenoma-a new manifestation of Gardner's syndrome. Endocr Res 2000; 26:783-90.

67. Chelaifa K, Bouzaidi K, Chouaib S, et al. Adrenal adenoma in a patient with Gardner's syndrome. A case report. Acta Radiol 2003; 44:158-9.

68. Kartheuser A, Walon C, West S, et al. Familial adenomatous polyposis associated with multiple adrenal adenomas in a patient with a rare 3' APC mutation. J Med Genet 1999; 36:65-7.

69. Marchesa P, Fazio VW, Church JM, et al. Adrenal masses in patients with familial adenomatous polyposis. Dis Colon Rectum 1997; 40:1023-8.

70. Naylor EW, Gardner EJ. Adrenal adenomas in a patient with Gardner's syndrome. Clin Genet 1981; 20:67-73.
71. Ozuner G, Hull TL. Familial desmoids in association with adrenal and ovarian masses and leiomyomas: report of three cases. Dis Colon Rectum 1999; 42:529-32.

72. Painter TA, Jagelman DG. Adrenal adenomas and adrenal carcinomas in association with hereditary adenomatosis of the colon and rectum. Cancer 1985; 55:2001-4.

73. Pines Corrales PJ, Gonzalez-Albarran O, Peralta M, et al. Clinically inapparent adrenal mass in a patient with familial adenomatous polyposis. Horm Res 2006; 66:207-10.

74. Smith TG, Clark SK, Katz DE, et al. Adrenal masses are associated with familial adenomatous polyposis. Dis Colon Rectum 2000; 43:1739-42.

75. Wakatsuki S, Sasano H, Matsui T, et al. Adrenocortical tumor in a patient with familial adenomatous polyposis: a case associated with a complete inactivating mutation of the APC gene and unusual histological features. Hum Pathol 1998; 29:302-6.

76. Yamakita N, Murai T, Ito Y, et al. Adrenocorticotropinindependent macronodular adrenocortical hyperplasia associated with multiple colon adenomas/carcinomas which showed a point mutation in the APC gene. Intern Med 1997; 36:536-42.

77. Herrera MF, Grant CS, van Heerden JA, et al. Incidentally discovered adrenal tumors: an institutional perspective. Surgery 1991; 110:1014-21.

78. Marshall WH, Martin FI, Mackay IR. Gardner's syndrome with adrenal carcinoma. Australas Ann Med 1967; 16:242-4.

79. Seki M, Tanaka K, Kikuchi-Yanoshita R, et al. Loss of normal allele of the APC gene in an adrenocortical carcinoma from a patient with familial adenomatous polyposis. Hum Genet 1992; 89:298-300.

80. Traill Z, Tuson J, Woodham C. Adrenal carcinoma in a patient with Gardner's syndrome: imaging findings. AJR $A m J$ Roentgenol 1995; 165:1460-1.

81. Grumbach MM, Biller BM, Braunstein GD, et al. Management of the clinically inapparent adrenal mass ("incidentaloma"). Ann Intern Med 2003; 138:424-9.

82. Gurbuz AK, Giardiello FM, Petersen GM, et al. Desmoid tumours in familial adenomatous polyposis. Gut 1994; 35:37781.

83. Clark SK, Phillips RK. Desmoids in familial adenomatous polyposis. Br J Surg 1996; 83:1494-504.

84. Knudsen AL, Bulow S. Desmoid tumour in familial adenomatous polyposis. A review of literature. Fam Cancer 2001; $1: 111-9$.

85. Jarvinen HJ. Desmoid disease as a part of familial adenomatous polyposis coli. Acta Chir Scand 1987; 153:379-83.

86. Bertario L, Russo A, Sala P, et al. Genotype and phenotype factors as determinants of desmoid tumors in patients with familial adenomatous polyposis. Int $J$ Cancer 2001; 95:102-7.

87. Heiskanen I, Jarvinen HJ. Occurrence of desmoid tumours in familial adenomatous polyposis and results of treatment. Int $J$ Colorectal Dis 1996; 11:157-62.

88. Clark SK, Neale KF, Landgrebe JC, et al. Desmoid tumours complicating familial adenomatous polyposis. Br J Surg 1999; 86:1185-9.

89. Hansmann A, Adolph C, Vogel T, et al. High-dose tamoxifen and sulindac as first-line treatment for desmoid tumors. Cancer 2004; 100:612-20.

90. Church JM. Desmoid tumours in patients with familial adenomatous polyposis. Semin Colon Rectal Surg 1995; 6:29-32.

91. Sturt NJ, Phillips RK, Clark SK. High-dose tamoxifen and sulindac as first-line treatment for desmoid tumors. Cancer 2004; 101:652.

92. Latchford AR, Sturt NJ, Neale K, et al. A 10-year review of surgery for desmoid disease associated with familial adenomatous polyposis. Br J Surg 2006; 93:1258-64.

93. Middleton SB, Phillips RK. Surgery for large intra-abdominal desmoid tumors: report of four cases. Dis Colon Rectum 2000; 43:1759-62. 
94. Ballo MT, Zagars GK, Pollack A. Radiation therapy in the management of desmoid tumors. Int J Radiat Oncol Biol Phys 1998; 42:1007-14.

95. Healy JC, Reznek RH, Clark SK, et al. MR appearances of desmoid tumors in familial adenomatous polyposis. AJR Am J Roentgenol 1997; 169:465-72.

96. Gebert JF, Dupon C, Kadmon M, et al. Combined molecular and clinical approaches for the identification of families with familial adenomatous polyposis coli. Ann Surg 1999; 229:350-61.

97. Vasen HF, van der Luijt RB, Slors JF, et al. Molecular genetic tests as a guide to surgical management of familial adenomatous polyposis. Lancet 1996; 348:433-5.

98. Vasen HF. Clinical diagnosis and management of hereditary colorectal cancer syndromes. J Clin Oncol 2000; 18:81S-92S.

99. Wu JS, Paul P, McGannon EA, et al. APC genotype, polyp number, and surgical options in familial adenomatous polyposis. Ann Surg 1998; 227:57-62.

100. Nieuwenhuis MH, De Vos Tot Nederveen Cappel W, Botmau A, et al. Desmoid tumors in a Dutch cohort of patients with familial adenomatous polyposis. Clin Gastroenterol Hepatol 2008; 6:215-9.

101. Wijn MA, Keller JJ, Brand HS. Oral and maxillofacial manifestations of familial adenomatosis polyposis. Gardner's syndrome. Ned Tijdschr Tandheelkd 2005; 112:340-4.

102. Kubo K, Miyatani H, Takenoshita Y, et al. Widespread radiopacity of jaw bones in familial adenomatosis coli. $J$ Craniomaxillofac Surg 1989; 17:350-3.

103. Gardner EJ, Plenk HP. Hereditary pattern for multiple osteomas in a family group. Am J Hum Genet 1952; 4:31-6.

104. Takeuchi T, Takenoshita Y, Kubo K, et al. Natural course of jaw lesions in patients with familial adenomatosis coli
(Gardner's syndrome). Int J Oral Maxillofac Surg 1993; 22:226-30.

105. Kimonis VE, Goldstein AM, Pastakia B, et al. Clinical manifestations in 105 persons with nevoid basal cell carcinoma syndrome. Am J Med Genet 1997; 69:299-308.

106. Ramaglia L, Morgese F, Filippella M, et al. Oral and maxillofacial manifestations of Gardner's syndrome associated with growth hormone deficiency: case report and literature review. Oral Surg Oral Med Oral Pathol Oral Radiol Endod 2007; 103:e30-4.

107. Giardiello FM, Hamilton SR, Krush AJ, et al. Nasopharyngeal angiofibroma in patients with familial adenomatous polyposis. Gastroenterology 1993; 105:1550-2.

108. Traboulsi EI, Krush AJ, Gardner EJ, et al. Prevalence and importance of pigmented ocular fundus lesions in Gardner's syndrome. N Engl J Med 1987; 316:661-7.

109. Bertario L, Russo A, Sala P, et al. Multiple approach to the exploration of genotype-phenotype correlations in familial adenomatous polyposis. J Clin Oncol 2003; 21:1698-707.

110. Valanzano R, Cama A, Volpe R, et al. Congenital hypertrophy of the retinal pigment epithelium in familial adenomatous polyposis. Novel criteria of assessment and correlations with constitutional adenomatous polyposis coli gene mutations. Cancer 1996; 78:2400-10.

111. Cetta F, Montalto G, Petracci M. Hepatoblastoma and APC gene mutation in familial adenomatous polyposis. Gut 1997; 41:417. 